Razin S. \& Knight B. C. J. G. (1960). J. gen. Microbiol. 22, 492-503

\title{
A Partially Defined Medium for the Growth of Mycoplasma
}

\author{
By S. RAZIN* AND B. C. J. G. KNIGHT \\ Department of Microbiology, University of Reading
}

\begin{abstract}
SUMMARY: The saprophytic Mycoplasma laidlawii strains A and B were grown in a partially defined medium composed of inorganic salts, Casamino acids, vitamins, nucleic acids, glucose and $10 \%(v / v)$ horse serum. The growth was less good than in the complex Edward medium; addition of known growth factors did not improve growth. Addition of yeast extract $(0.05 \%, w / v)$ to the partially defined medium allowed growth equivalent to that in Edward medium. The serum could be replaced by $1 \%(w / v)$ crystallized bovine plasma albumin. The suboptimal growth obtained in the albumin-containing medium was not improved by adding cholesterol, Tween 80, lecithin and other growth factors known to be required by other Mycoplasma spp. Riboflavin and nicotinic acids were the only vitamins found to be essential for the growth of $M$. laidlawii strain $A$ in the albumin medium. The Casamino acids could be replaced by a mixture of known amino acids. The pathogenic $M$. mycoides var, capri and $M$. bovigenitalium grew in the partially defined medium when the concentration of the serum was increased to $20 \%(\mathrm{v} / \mathrm{v})$ and yeast extract added to a final concentration of $0.05 \%(w / v)$.
\end{abstract}

The organisms of the genus Mycoplasma (pleuropneumonia-like organisms; PPLO) are nutritionally very exacting and rich complex media are used for their laboratory cultivation. These media usually contain ox-heart infusion, peptone, yeast extract and serum (Klieneberger, 1936; Edward, 1947; Morton, Smith \& Leberman, 1951). Some attempts have been made to simplify these media by replacing the serum by mixtures of: cholesterol, bovine serum albumin and an acetone-insoluble lipid of egg yolk (Edward \& Fitzgerald, 1951); cholesterol, lipoprotein, lecithin and acetate (Smith \& Lynn, 1958); cholesterol, 'heat-stable protein' and oleic acid (Rodwell, 1956). A partially defined medium devised by Smith (1955) enabled suboptimal growth of a few Mycoplasma strains; this medium contained some chemically undefined components such as serum lipoprotein and ash of Bacto-peptone.

Our aim was to compound a culture medium for Mycoplasma which should be as chemically defined as possible and which might enable a more rational study of nutritional requirements to be made. The saprophytic Mycoplasma laidlawii strains originally isolated from sewage (Laidlaw \& Elford, 1936), which are less exacting than the parasitic strains (Edward, 1954), were chosen as main test organisms.

\section{ME'THODS}

Organisms. The saprophytic Mycoplasma laidlawii strain A (sewage A, PG 8), M. laidlawii strain B (Sewage B, PG 9) and the bovine strain M. bovi-

* Present address : Department of Clinical Microbiology, Hebrew University, Hadassah Medical School, Jerusalem, Israel. 
genitalium (PG 12) were kindly given by Dr D. G. ff. Edward (The Wellcome Research Laboratories, Beckenham, Kent). M. mycoides var. capri (goat pleuropneumonia organism) was the gift of Dr E. Klieneberger-Nobel (The Lister Institute for Preventive Medicine, London). M. laidlawii strain A was used for most of the work to be described.

Media. A modified Edward medium (Butler \& Knight, 1960b) was used for keeping stock cultures and for growing the organisms to be used as inoculum in the nutrition experiments. The same medium solidified with $2 \%(w / v)$ agar was used for viable counts (Butler \& Knight, 1960a). The partially defined medium finally evolved (Table 1) was prepared by mixing volumes of several stock solutions as follows:

(1) 84 vol. of inorganic salts and amino acid solution. The solution was brought to $\mathrm{pH} 8.3$ before autoclaving for $20 \mathrm{~min}$. at $121^{\circ}$.

(2) 10 vol. of horse serum (Burroughs Wellcome: normal no. 2).

(3) 2 vol. of vitamins solution, sterilized by passage through a sintered glass filter.

(4) 1 vol. of $0.5 \%(w / v)$ solution of sodium salts of ribonucleic and deoxyribonucleic acids, sterilized by filtration.

(5) 2 vol. of $37 \%(w / v)$ glucose solution; sterilized by filtration.

(6) 1 vol. of penicillin solution (20,000 units $/ \mathrm{ml}$.).

All stock solutions were prepared in demineralized water obtained from a Mark III portable Deminrolit Plant (Permutit Co. Ltd., London, W. 4), stored at $4^{\circ}$ and used within a month. Penicillin solutions were freshly prepared before use. The complete medium was adjusted to $\mathrm{pH} 8 \cdot 3$ by adding sterile $\mathrm{N}-\mathrm{NaOH}$.

Pyrex glassware was used in all experiments; before use it was cleaned in chromic + sulphuric acid mixture and thoroughly rinsed with distilled water.

The medium was dispensed in $10 \mathrm{ml}$. quantities in 6 in. $\times \frac{5}{8}$ in. test tubes or in 1 -shaped tubes (van Heyningen \& Gladstone, 1953).

Sterilization of the various chemicals added to the basal medium as supplements was carried out either by autoclaving for $20 \mathrm{~min}$. at $121^{\circ}$ or, when heatlabile, by suction through sintered-glass bacterial filters.

Conditions of growth. Ten ml. liquid Edward medium in a $\perp$-shaped tube were inoculated with $0.1 \mathrm{ml}$. stock culture and rocked gently in a $37^{\circ}$ water bath for $24 \mathrm{hr}$. The organisms were harvested and washed according to Butler \& Knight $(1960 a)$. Each tube of experimental medium received $0 \cdot 1 \mathrm{ml}$. of a $1 / 10$ dilution of the washed suspension. Viable counts showed the initial inoculum to contain c. $10^{5}$ viable particles $/ \mathrm{ml}$. medium. Inoculated test tubes were incubated statically in air at $37^{\circ}$ and the $\perp$-shaped tubes were rocked in a $37^{\circ}$ water bath. Growth was usually estimated after incubation for $96 \mathrm{hr}$.

Assessment of growth. The extent of growth was measured by : $(a)$ the viable count technique as described by Butler \& Knight (1960a); (b) titratable acid which was estimated by titrating cultures in media containing glucose with $0.01 \mathrm{~N}-\mathrm{NaOH}$ to $\mathrm{pH} 8 \cdot 3$, as measured by a glass electrode; uninoculated media served as controls. The two techniques gave results in agreement.

Chemicals. Most of the inorganic and organic chemicals were analytical reagents. Ribonucleic acid, $\mathrm{Na}$ salt from yeast (Na-RNA) was the product of 
L. Light and Co. Ltd., Colnbrook, Bucks.; it was further purified by the method of Frisch-Niggemeyer \& Reddi (1957). Deoxyribonucleic acid, Na salt from thymus gland (Na-DNA) was obtained from the British Drug Houses Ltd., Poole, England. Crystallized bovine plasma albumin was the product of Armour Laboratories, Hampden Park, Eastbourne, Sussex; a 10\% (w/v) solution in demineralized water was sterilized by filtration. Cholesterol (British Drug Houses Ltd) was recrystallized twice from ethanol. A solution containing $30 \mathrm{mg}$. cholesterol $/ \mathrm{ml}$. was prepared in absolute ethanol and sterilized by filtration. Addition of cholesterol to the media was performed by injecting, with the aid of a syringe, small volumes of the warm ethanolic solution. Tween 80 (T. B. culture grade, Honeywell and Stein Ltd., Devonshire House, Mayfair Place, Piccadilly, London, W. 1) was purified by ether extraction as described by Davies (1947 a ) and kept as a $10 \%(\mathrm{w} / \mathrm{v})$ solution at $-20^{\circ}$. Lecithin (egg; British Drug Houses Ltd.) was purified by acetone precipitation from ethereal solution (repeated three times) according to the method used by Edward \& Fitzgerald (1951). Charcoal (animal) was the product of Hopkin and Williams, Ltd., Chadwell Heath, Essex, England.

Dialysis of horse serum. Forty ml. horse serum (Burroughs Wellcome; normal no. 2) were put into a cellophan bag (Visking, 0.85 in.) and dialysed at $4{ }^{\circ}$ against $4 \mathrm{l}$. demineralized water; the water was changed after $20 \mathrm{hr}$. After a further $5 \mathrm{hr}$. the water was replaced by salt solution (g./l.: $\mathrm{Na}_{2} \mathrm{HPO}_{4}, 5 \cdot 5$; $\mathrm{KH}_{2} \mathrm{PO}_{4}, 0.27 ; \mathrm{NaCl}, 2 \cdot 9 ; \mathrm{MgSO}_{4} .7 \mathrm{H}_{2} \mathrm{O}, 0.18 ; \mathrm{pH} 8.0$ ), and the dialysis continued for $19 \mathrm{hr}$. The dialysed serum was then sterilized by suction through a sintered-glass filter.

\section{RESULTS}

\section{The development of the partially defined medium}

Eagle's tissue culture medium (Eagle, Oyama, Levy \& Freeman, 1957) was chosen as a basis for compounding our medium. After various modifications of the original Eagle's medium a partially defined medium was achieved which enabled good multiplication of the saprophytic Mycoplasma laidlawii strains A and $B$. The ingredients of this medium are given in Table 1. Later work has shown that not all the compounds listed in Table $I$ are essential. But the medium given was used as a basis for the work described here. The development of the medium and comments on its major components follow.

Inorganic salts. The bicarbonate buffer included in Eagle's medium was replaced by phosphate buffer, since bicarbonate was not found to be essential for growth. The concentration of buffer in the medium was important. The acid produced by the organisms from glucose during growth causes a decrease in the pH value of the medium; below pH 7.0 multiplication stops (Laidlaw \& Elford, 1936; and our observations). Different concentrations of phosphate buffer were therefore tested; $0.02-0.03 \mathrm{M}$ was found to enable best growth. Lower concentrations had not sufficient buffering capacity and higher concentrations became somewhat toxic (Fig. 1). A concentration of 0.03 M-phosphate buffer was chosen.

$\mathrm{CaCl}_{2}$ and $\mathrm{Fe}\left(\mathrm{NO}_{3}\right)_{3}$, which are constituents of Eagle's medium, could be eliminated without affecting growth. Ash of Bacto-peptone and $\mathrm{SnCl}_{2} \cdot 2 \mathrm{H}_{2} \mathrm{O}$, 
which were reported to stimulate growth of some Mycoplasma organisms in the medium of Smith (1955), had no stimulatory effect when tested in our medium.

Casamino acids. The concentration of Casamino acids (Bacto vitamin-free Casamino acids, acid hydrolysed) optimal for growth was $1 \%(w / v)$. Below and above this concentration there was less growth and it was much delayed

Table 1. The ingredients of the partially defined medium for various

\section{Mycoplasma strains}

Inorganic salts (g./l.)

$\begin{array}{ll}\mathrm{NaCl} & 6 \cdot 8 \\ \mathrm{KCl} & 0 \cdot 4 \\ \mathrm{MgSO}_{4} .7 \mathrm{H}_{2} \mathrm{O} & 0 \cdot 2 \\ \mathrm{Na}_{2} \mathrm{HPO}_{4} & 4 \cdot 1 \\ \mathrm{KH}_{2} \mathrm{PO}_{4} & 0 \cdot 1\end{array}$

Vitamins (mg./1.)

$\begin{array}{ll}\text { Thiamin } & \mathbf{2 \cdot 5} \\ \text { Riboflavin } & \mathbf{2 \cdot 5} \\ \text { Pyridoxine-HCl } & \mathbf{2 \cdot 5} \\ \text { Pyridoxal-HCl } & \mathbf{2 \cdot 5} \\ \text { Nicotinic acid } & \mathbf{2 \cdot 5} \\ \text { Nicotinamide } & \mathbf{2 \cdot 5} \\ \text { Pantothenic acid } & \mathbf{2 \cdot 5} \\ \text { (Ca salt) } & \\ \text { Folic acid } & \mathbf{2 \cdot 5} \\ \text { Choline-HCl } & \mathbf{2 \cdot 5} \\ \text { m-Inositol } & \mathbf{2 \cdot 5}\end{array}$

\begin{tabular}{ll}
\multicolumn{2}{c}{ Amino acids (g./l.) } \\
Bacto vitamin-free 10 \\
$\begin{array}{l}\text { Casamino acids (acid } \\
\text { hydrolysed) }\end{array}$ \\
DL-Cystine & 0.03 \\
DL-Tryptophan & 0.03
\end{tabular}

Miscellaneous

$\begin{array}{ll}\text { Glucose } & 7.5 \mathrm{~g} .1 . \\ \text { Horse serum } & 10 \%(\mathrm{v} / \mathrm{v}) \\ \text { Ribonucleic acid } & \mathbf{5 0} \mathrm{mg} . / \mathrm{l} . \\ \text { Deoxyribonucleic acid } & 50 \mathrm{mg} . / \mathrm{l} . \\ \text { Penicillin G } & 200 \mathrm{units} / \mathrm{ml} .\end{array}$

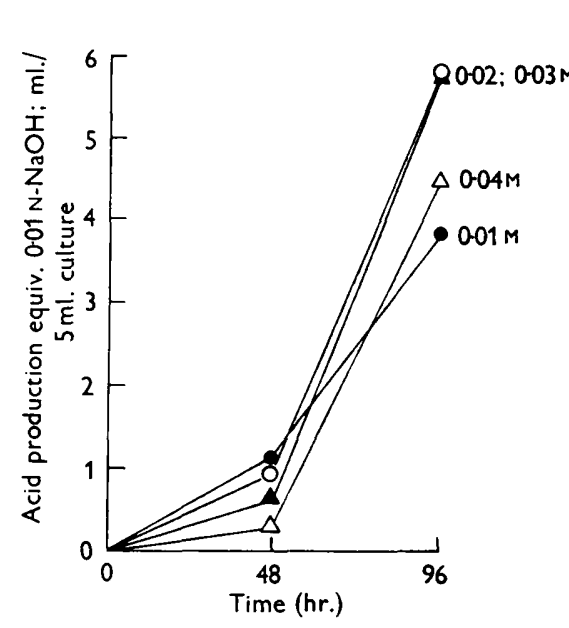

Fig. 1

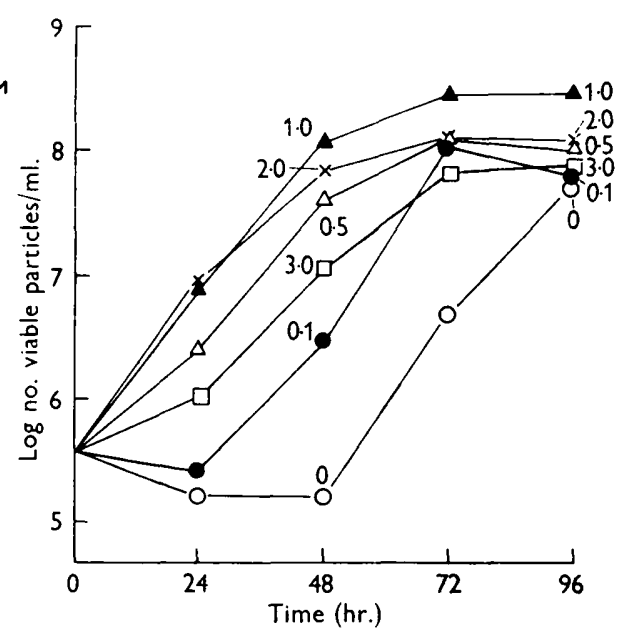

Fig. 2

Fig. 1. The effect of phosphate buffer concentration in the partially defined medium on the growth of Mycoplasma laidlazii strain A. Test tubes contained $10 \mathrm{ml}$. medium with different concentrations of $\mathrm{Na}_{2} \mathrm{HPO}_{4}-\mathrm{KH}_{2} \mathrm{PO}_{4}$ buffer. Initial inoculum $1.5 \times 10^{5}$ viable particles $/ \mathrm{ml}$. Acid production determined after incubation at $37^{\circ}$ for 48 and $96 \mathrm{hr}$.

Fig. 2. The growth of Mycoplasma laidlawii strain A in the partially defined medium which contained different amounts $(\%, w / v$, as indicated) of Bacto vitamin-free Casamino acids. The 1 -shaped tubes contained $10 \mathrm{ml}$. medium and were rocked in a $37^{\circ}$ water bath. 
(Fig. 2). However, some growth occurred even without addition of Casamino acids, probably because of the small amounts of amino acids supplied by the serum. Raising the concentration of DL-cystine and DL-tryptophan, which supplemented the Casamino acids, from 30 to $240 \mathrm{mg}$./l. had no effect on the growth. L-Cysteine-HCl at $1000 \mathrm{mg}$./l. suppressed growth.

Vitamins. Eagle's vitamin mixture supported suboptimal growth only. Increasing the concentration of all vitamins $2 \cdot 5$-fold and that of riboflavin 25-fold, and the addition of nicotinic acid $(2.5 \mathrm{mg}$./l.) markedly improved growth.

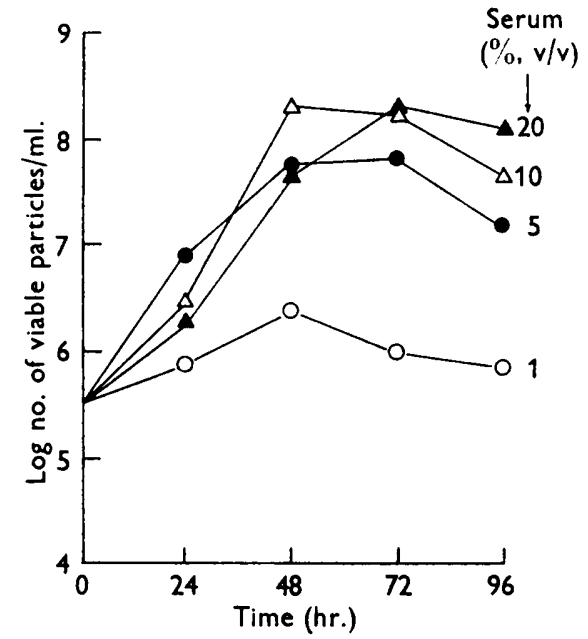

Fig. 3

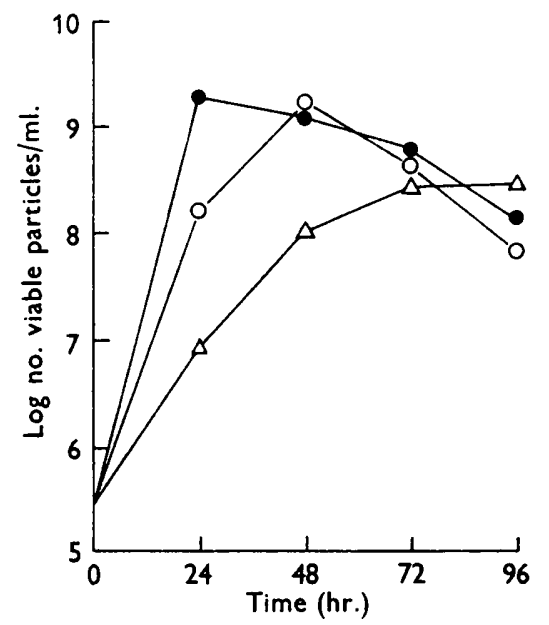

Fig. 4

Fig. 3. The effect of the serum concentration in the partially defined medium on the growth of Mycoplasma laidlawii strain A. The $\perp$-shaped tubes contained $10 \mathrm{ml}$. medium with different amounts $(\%, v / v)$ of serum as indicated. The tubes were rocked in a $37^{\circ}$ water bath.

Fig. 4. The growth of Mycoplasma laidlareii strain A in the partially defined medium $(\triangle)$; in the partially defined medium $+0.05 \%(w / v)$ yeast extract $(O)$; in Edward medium (๑). The $\perp$-tubes contained $10 \mathrm{ml}$. medium and were rocked in a $37^{\circ}$ water bath.

Glucose. The strains of Mycoplasma laidlawii tested are able to metabolize glucose (Edward, 1950); decrease of glucose concentration in the medium from 0.75 to $0.1 \%(\mathrm{w} / \mathrm{v})$ had no effect on the growth. The presence of this fermentable carbohydrate in the medium at $0.75 \%(w / v)$ made possible the rapid assessment of growth by the acid titration method.

Horse serum. Best growth of the saprophytic Mycoplasma strains was obtained when the concentration of the serum in the partially defined medium was $20 \%(\mathrm{v} / \mathrm{v})$. However, decrease of the serum content to $10 \%(\mathrm{v} / \mathrm{v})$ had a very little adverse effect on the growth and therefore the latter concentration was chosen. The organisms of the inoculum survived without multiplication when the serum concentration was decreased to $1 \%(v / v)$ (Fig. 3). They died rapidly when the serum was completely eliminated.

Nucleic acids. Components supplied by ribonucleic and by deoxyribonucleic 
acids were essential for growth of Mycoplasma laidlawii strain A; M. laidlawii strain B and M. mycoides var. capri required DNA components only (Razin \& Knight, 1960b).

Penicillin. This antibiotic was added as a precaution against contamination during the long incubation periods used in the experiments. Penicillin in the concentration used has no inhibitory effect on the growth of the Mycoplasma organisms (Edward \& Freundt, 1956).

\section{Experiments to improve the partially defined medium}

Although a reasonable degree of growth of the saprophytic Mycoplasma strains was obtained in the partially defined medium this was inferior to growth in the rich Edward medium. The addition of a small amount of yeast extract (Oxoid; $0.05 \%, \mathrm{w} / \mathrm{v}$ ) to the partially defined medium gave growth comparable to that in Edward medium (Fig. 4). This indicated that some material which is present in yeast extract was missing from the partially defined medium or was present in too low a concentration. Various compounds were tested for ability to replace the yeast factor, namely: L-glutamine, cholesterol, lecithin, Tween 80, spermine, haematin, vitamin $K_{3}$ (2-methyl-1 :4naphthoquinone), adenosine triphosphate, diphosphopyridine nucleotide, various purines, pyrimidines, nucleosides and nucleotides, sodium acetate, sodium lactate, glycerol. Some of these compounds have been reported by various authors to be essential for, or to stimulate, the growth of other Mycoplasma organisms. The compounds were tested over a range of concentrations, singly or in various mixtures, but none of them was found to improve growth significantly; some even inhibited growth in certain concentrations. Experiments to separate and characterize the growth factor(s) present in yeast extract have not yet been made.

\section{Replacement of the serum in the partially defined medium}

The presence of horse serum in the partially defined medium prevented its use for the determination of the amino acid and vitamin requirements of the organisms, although it did not interfere with testing for the nucleic acid requirements (Razin \& Knight, 1960b). Experiments to eliminate the serum from the medium were therefore carried out. Mycoplasma laidlawii strain A died very quickly when serum was omitted from the medium, but survived without multiplication when the serum concentration was $1 \%(v / v)$. Good growth occurred only when the concentration of the serum was raised to $10 \%$ $(\mathrm{v} / \mathrm{v})$ (Fig. 3). When $10 \%(\mathrm{v} / \mathrm{v})$ of dialysed serum were added to the medium growth occurred only after a very long $(76 \mathrm{hr}$.) lag period. This suggests that small molecules (? salts) of the serum were important. M. laidlawii strain A survived but did not multiply when the serum was replaced by $1 \%(w / v)$ of charcoal or soluble starch. Good multiplication was obtained when the serum was replaced by crystallized bovine plasma albumin; the optimal concentration was $0.5 \%(\mathrm{w} / \mathrm{v})$; growth was then slightly less than that with $10 \%(\mathrm{v} / \mathrm{v})$ serum (Fig. 5). 
Various additions to the albumin-containing medium were tried in order to improve growth. Cholesterol, Tween 80 and lecithin, singly or in mixtures, were ineffective when tested over a wide range of concentrations. Lecithin inhibited growth slightly when tested in concentrations higher than $10 \mu \mathrm{g} . / \mathrm{ml}$. Unpurified Tween 80, which apparently contained a high percentage of free oleic acid, was toxic in concentrations higher than $0.001 \mathrm{mg} . / \mathrm{ml}$.; purification eliminated this toxicity and then growth was not affected even by $0.50 \mathrm{mg} . / \mathrm{ml}$. of the purified material. Cholesterol had no effect on the growth in concentrations ranging from 0.001 to $0.30 \mathrm{mg}$. $/ \mathrm{ml}$. A mixture of cholesterol and Tween 80 (each $0.05 \mathrm{mg} . / \mathrm{ml}$.) did not replace the albumin in the medium. Sodium acetate, reported to stimulate growth of some Mycoplasma organisms (Smith \& Lynn, 1958) did not improve growth in the albumin-containing medium; it inhibited growth at concentrations higher than $1 \mathrm{mg} . / \mathrm{ml}$. Similar results were obtained with sodium lactate and glycerol, which were reported to be essential for growth of $M$. mycoides var. mycoides (Rodwell, 1960); sodium lactate inhibited growth of $M$. laidlawii strain $A$ even at $1 \mathrm{mg} . / \mathrm{ml}$. The addition of vitamin $\mathbf{B}_{12}$, biotin or spermine did not improve growth; spermine inhibited growth at $10 \mu \mathrm{g} . / \mathrm{ml}$.

Table 2. The composition of the amino acid mixtures tested for replacing the Casamino acids in the partially defined medium

\begin{tabular}{|c|c|c|c|c|c|c|}
\hline & & & No. & mixtı & & \\
\hline & 1 & 2 & $\mathbf{3}$ & 4 & $\mathbf{5}$ & 6 \\
\hline Amino acid & & antitie & of am & 0 acid & Ig. $/ 100$ & \\
\hline Glycine & 5 & $\mathbf{0}$ & $\mathbf{0}$ & 1 & 32 & $\mathbf{0}$ \\
\hline DL-Leucine & 12 & 2 & $\mathbf{0}$ & 25 & 100 & 20 \\
\hline L-Tyrosine & 4 & 1.8 & $\mathbf{0}$ & $\mathbf{3 0}$ & $1 \cdot 3$ & 20 \\
\hline L-Hydroxyproline & $\mathbf{5}$ & $\mathbf{0}$ & $\mathbf{0}$ & 49 & $\mathbf{0}$ & 100 \\
\hline L-Histidine & 2 & $0 \cdot 6$ & $\mathbf{0}$ & 10 & 35 & 10 \\
\hline L-Arginine & $\overline{7}$ & $1 \cdot 7$ & 7 & 25 & 47 & 20 \\
\hline DL-Alanine & 5 & 0 & $\mathbf{0}$ & 10 & 0 & 0 \\
\hline DL-Serine & $\mathbf{5}$ & $\mathbf{0}$ & $\mathbf{0}$ & 4 & 20 & 20 \\
\hline DL-Valine & 5 & $1 \cdot 7$ & $\mathbf{0}$ & 40 & 190 & 20 \\
\hline DL-Isoleucine & 4 & $2 \cdot 6$ & 4 & 25 & 145 & 20 \\
\hline DL-Tryptophan & 2 & $0 \cdot 6$ & 2 & 0 & 20 & 0 \\
\hline DL-Phenylalanine & $\mathbf{5}$ & $2 \cdot 6$ & 5 & 20 & 100 & $\mathbf{0}$ \\
\hline DL-Aspartic acid & 6 & 0 & 6 & 20 & 200 & 20 \\
\hline L-Lysine-HCl & 7 & $\mathbf{2 \cdot 2}$ & $\mathbf{0}$ & 20 & 110 & 20 \\
\hline L-Glutamic acid & $7 \cdot 5$ & $\mathbf{0}$ & $7 \cdot 5$ & 100 & 315 & $\mathbf{0}$ \\
\hline DL-Methionine & 3 & 0.7 & $1 \cdot 5$ & 20 & $\mathbf{5 4}$ & 20 \\
\hline L-Cystine & 2 & 1 & 0 & $\mathbf{0}$ & 10 & $\mathbf{0}$ \\
\hline DL-Threonine & 6 & $1 \cdot 8$ & 0 & $\mathbf{0}$ & 100 & 100 \\
\hline L-Cysteine-HCl & 26 & $\mathbf{0}$ & $0 \cdot 1$ & $\mathbf{0}$ & 0 & 10 \\
\hline L-Glutamine & 10 & 30 & 10 & $\mathbf{0}$ & $\mathbf{0}$ & $\mathbf{0}$ \\
\hline
\end{tabular}




\section{Vitamin requirements}

Although growth in the albumin-containing medium was suboptimal (as compared with serum medium) this medium was adequate for testing the vitamin requirements of $\mathbf{M y c o p l a s m a ~ l a i d l a w i i}$ strain $\mathbf{A}$. The ten vitamins were omitted from the medium one by one. Riboflavin and nicotinic acid were the only vitamins found to be required.

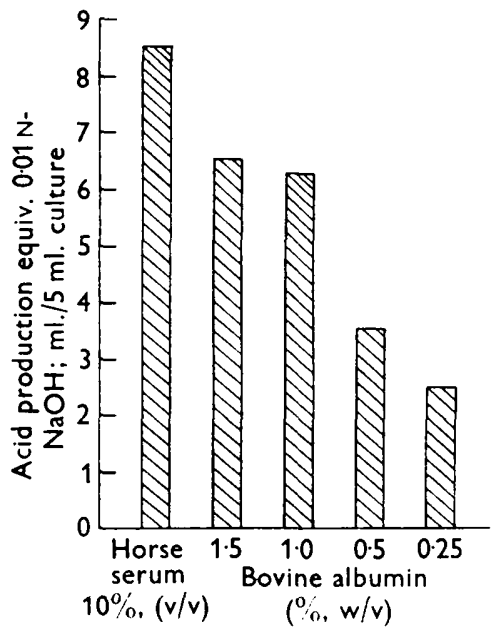

Fig. 5

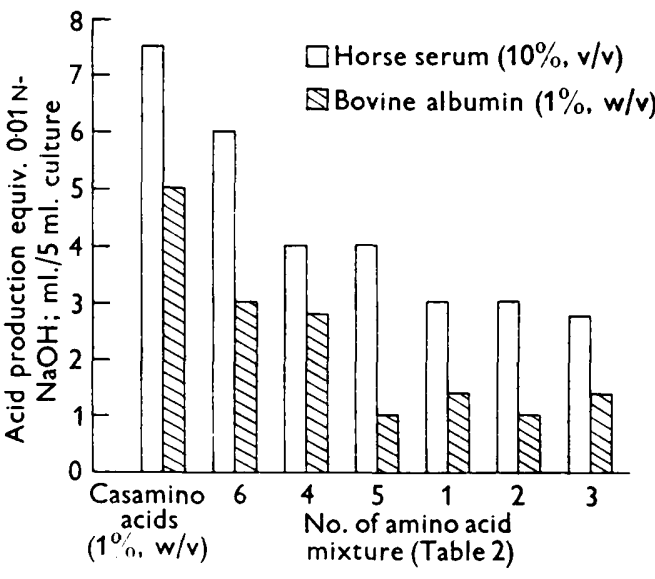

Fig. 6

Fig. 5. Effect of replacing the serum of the partially defined medium by crystallized bovine plasma albumin. Test tubes contained $10 \mathrm{ml}$. medium with different concentrations of albumin or with $10 \%(\mathrm{v} / \mathrm{v})$ horse serum. Initial inoculum $6 \times 10^{5}$ viable particles $/ \mathrm{ml}$. of Mycoplasma laidlawii strain A. Acid production was determined after incubation at $37^{\circ}$ for $96 \mathrm{hr}$.

Fig. 6. Effects of replacing the Casamino acids of the partially defined medium by amino acid mixtures. Test tubes contained $10 \mathrm{ml}$. medium with different amino acid mixtures and either $10 \%(\mathrm{v} / \mathrm{v})$ of serum or with $1 \%(\mathrm{w} / \mathrm{v})$ of crystallized bovine plasma albumin. Initial inoculum $3 \times 10^{5}$ viable particles/ml. of Mycoplasma laidlawii strain A. Acid production determined after incubation at $37^{\circ}$ for $113 \mathrm{hr}$.

\section{Replacement of the Casamino acids by amino acid mixtures}

Replacement of Casamino acids by known amino acid mixtures was tried with the partially defined medium, which contained either $10 \%(\mathrm{v} / \mathrm{v})$ horse serum or $1 \%(\mathrm{w} / \mathrm{v})$ crystallized bovine plasma albumin. The amino acid mixtures tested were compounded according to various authors who had used them in defined media for tissue cultures or for micro-organisms (Table 2). None of the six amino acid mixtures tested replaced the Casamino acids completely. Best growth was obtained with the amino acid mixture used by Traub, Mager \& Grossowicz (1955) for growing Pasteurella tularensis (Fig. 6). In general the amino acid mixtures used for cultivating micro-organisms proved better than those used for tissue cultures. 
The growth of other Mycoplasma organisms in the partially defined medium

As mentioned before, Mycoplasma laidlawii strain B grew well on the partially defined medium. This organism differed from strain $\mathbf{A}$ in not requiring RNA (Razin \& Knight, 1960b). The pathogenic organisms $M$. mycoides var. capri and $M$. bovigenitalium did not grow in the partially defined medium. Increasing the serum concentration from 10 to $20 \%(\mathrm{v} / \mathrm{v})$ and addition of $0.05 \%(\mathrm{w} / \mathrm{v}$ ) yeast extract (Oxoid) to the medium enabled good growth of these organisms to occur. Increasing the concentration of DNA from 50 to $500 \mu \mathrm{g}$. 1 $\mathrm{ml}$. in this fortified medium allowed optimal growth of $\boldsymbol{M}$. mycoides var. capri

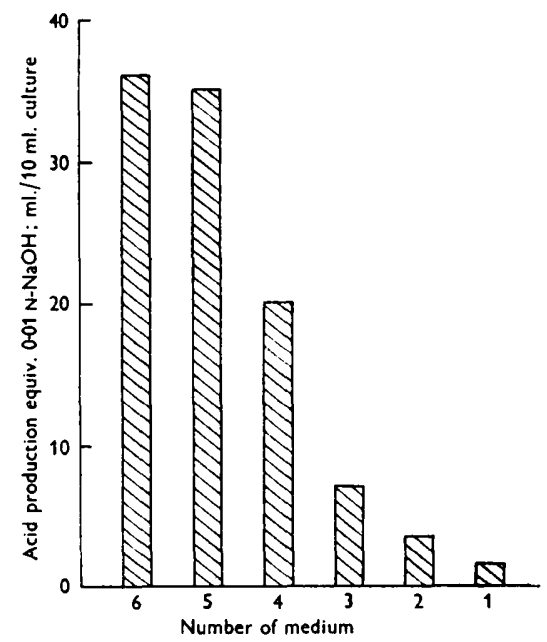

Fig. 7. Growth of Mycoplasma mycoides var. capri in the partially defined medium containing: (1) $10 \%$ (v/v) serum; (2) $20 \%$ (v/v) serum; (3) $10 \%$ (v/v) serum $+0.05 \%$ (w/v) yeast extract; (4) $20 \%(\mathrm{v} / \mathrm{v})$ serum $+0.05 \%(\mathrm{w} / \mathrm{v})$ yeast extract; (5) as (4) but with Na-DNA $500 \mu \mathrm{g} . / \mathrm{ml}$. instead of $50 \mu \mathrm{g} . / \mathrm{ml}$.; (6) Edward medium supplemented with glucose $0 \cdot 75 \%(w / v)$. Test tubes contained $10 \mathrm{ml}$. of each medium. Initial inoculum $2 \times 10^{\circ}$ viable particles $/ \mathrm{ml}$. Acid production determined after incubation at $37^{\circ}$ for $96 \mathrm{hr}$.

which was similar to the amount of growth obtained in the rich Edward medium (Fig. 7). This organism produced much more acid than the saprophytic Mycoplasma strains. M. bovigenitalium does not ferment glucose, therefore estimation of its growth by the acid titration method could not be made. Viable counts showed its multiplication in the partially defined medium fortified by increasing the serum to $20 \%(\mathrm{v} / \mathrm{v})$ and adding yeast extract to $0.05 \%(w / v)$ to be comparable to that in Edward medium.

\section{DISCUSSION}

Our results show the nutritional requirements of the saprophytic Mycoplasma strains used (sewage $\mathbf{A}$ and B) to be quite complex. Although Laidlaw \& Elford (1936) reported 'fairly satisfactory growth' of $M$. laidlawii strains A and $B$ in Hartley's broth without the addition of serum, experiments (Butler \& 
Knight, 1960c) failed to show significant growth of these organisms in a peptone + yeast-extract medium in the absence of serum. The serum, which is an important component of the partially defined medium, seems to have a dual function: (a) neutralization of toxic agents (? traces of fatty acids) present in the medium; (b) supply of growth factors. This interpretation is based on the finding that the organisms died rapidly in the absence of serum but survived when $1 \%(\mathrm{v} / \mathrm{v})$ serum was added to the medium. The protective function of the serum could be fulfilled by charcoal, starch or crystallized bovine plasma albumin, all of which have the ability to absorb unsaturated fatty acids (Ley \& Mueller, 1946; Davis \& Dubos, 1947; Pollock, 1949). Albumin also allowed some growth in the partially defined medium without serum.

The growth of the saprophytic Mycoplasma laidlawii strains A and B in the albumin-containing medium in the complete absence of serum is of interest, since this medium is apparently free from cholesterol which has been found essential for the growth of all the parasitic Mycoplasma spp. tested (Edward \& Fitzgerald, 1951; Smith, Lecce \& Lynn, 1954; Rodwell, 1956). The possibility that the saprophytic strains require only trace amounts of cholesterol, which was being supplied as a contaminant of the crystallized bovine albumin, seems unlikely; no cholesterol was detected even in the less purified bovine albumin fraction V (Edward, 1953). The addition of cholesterol alone, or with Tween 80 and lecithin, to the albumin-containing medium did not improve growth. Hence, it seems that cholesterol is not essential at least for some degree of multiplication of the saprophytic Mycoplasma laidlawii strains $\mathbf{A}$ and $\mathbf{B}$. Edward \& Freundt (1956), who stressed the importance of the cholesterol requirement as a criterion for distinguishing Mycoplasma spp. from bacteria, mentioned the possibility that the saprophytic strains might be found to be exceptional in this respect. However, Butler \& Knight (1960c) found a marked stimulation of the growth of $M$. laidlawii strain $\mathbf{A}$ in a peptone yeast-extract medium by adding cholesterol. It must also be remembered that the growth in the present albumin-containing medium was much less than in Edward medium. Thus our failure to get a growth response to the addition of cholesterol might be due to a deficiency of other growth factors which limited the growth of Mycoplasma laidlawii in the albumin medium. On the present evidence it seems possible that the growth-promoting effects of cholesterol observed by Butler \& Knight $(1960 c)$ may have been due to a detoxicating effect, e.g. against traces of fatty acids such as has been noted by Pollock (1949) and Kodicek (1949) in their reviews. Thus no final conclusion about the cholesterol requirement of the saprophytic strains can yet be drawn; further work is required.

The vitamin requirements of Mycoplasma laidlawii strain A, riboflavin and nicotinic acid, are similar to those of $M$. mycoides var. mycoides which requires riboflavin, nicotinic acid and thiamine (Rodwell, 1960). It may be of interest to mention here the requirement for riboflavin in the growth of the L-phases of certain Gram-negative bacteria (Tulasne, Terranova \& Lavillaureix, 1955).

The Casamino acids of the partially defined medium could be replaced by 
certain amino acid mixtures; better growth was obtained with mixtures which contained rather high concentrations of amino acids. The mixtures used for tissue culture media, which contained low concentrations of amino acids, gave poor growth. On the other hand, the mixture of Kaufman \& Humphries (1958) which contained a very high concentration of amino acids (equivalent to $2.5 \%$, $\mathbf{w} / \mathrm{v}$, Casamino acids) gave inferior growth. These results are in accordance with the present findings that the concentration of Casamino acids optimal for the growth of Mycoplasma laidlawii strains A and B was rather high (1\%,w/v), but that still higher concentrations decreased growth. Growth inhibition by high concentrations of amino acids is well known (Magasanik, 1957).

We wish to thank our colleague Mr M. Butler for his assistance. One of us (S.R.) is indebted to the Friends of the Hebrew University of Jerusalem for the award of a Michael and Anna Wix Trust Fellowship. A grant from the Agricultural Research Council in support of this work is gratefully acknowledged.

\section{REFERENCES}

Butler, M. \& Knight, B. C. J. G. (1960a). The survival of washed suspensions of Mycoplasma. J. gen. Microbiol. 22, 470.

Butler, M. \& Knight, B. C. J. G. $(1960 b)$. The measurement of the growth of Mycoplasma in liquid media. J. gen. Microbiol. 22, 478.

ButLER, M. \& KNIGHT, B. C. J. G. (1960c). Steroid growth-requirements and steroid growth inhibitors of Mycoplasma. J. gen. Microbiol. 22, 483.

DAvis, B. D. (1947a). The preparation and stability of fatty acid-free polyoxyethylene sorbitan monooleate ('Tween' 80). Arch. Biochem. 15, 359.

DAvis, B. D. \& Dubos, R. J. (1947 $b$ ). The binding of fatty acids by serum albumin, a protective growth factor in bacteriological media. J. exp. Med. 86, 215.

Eagle, H., Oyama, V. I., Levy, M. \& Freeman, A. E. (1957). myo-Inositol as an essential growth factor for normal and malignant human cells in tissue culture. J. biol. Chem. 226, 191.

EDWARD, D. G. FF. (1947). A selective medium for pleuropneumonia-like organisms. J. gen. Microbiol. 1, 238.

EDWARD, D. G. FF. (1950). An investigation of the biological properties of organisms of the pleuropneumonia group, with suggestions regarding the identification of strains. J. gen. Microbiol. 4, 311.

EDward, D. G. FF. (1953). A difference in growth requirements between bacteria in the L-phase and organisms of the pleuropneumonia group. J. gen. Microbiol. 8, 256.

EDWARD, D. G. FF. (1954). The pleuropneumonia group of organisms: a review, together with some new observations. J. gen. Microbiol. 10, 27.

Edward, D. G. FF. \& Fitzgerald, W. A. (1951). Cholesterol in the growth of the pleuropneumonia group. J. gen. Microbiol. 5, 576.

Edward, D. G. FF. \& Freundt, E. A. (1956). The classification and nomenclature of organisms of the pleuropneumonia group. J. gen. Microbiol. 14, 197.

Frisch-Niggemeyer, W. \& Reddi, K. K. (1957). Studies of ribonuclease in tobaccoleaves. 1. Purification and properties. Biochim. biophys. Acta, 26, 40.

Healy, G. M., Fisher, D. C. \& Parker, R. C. (1954). Nutrition of animal cells in tissue culture. IX. Synthetic medium no. 703. Canad. J. Biochem. Physiol. 32, 327.

Heyningen, W. E. van \& Gladstone, G. P. (1953). The neurotoxin of Shigella shigae III. The effect of iron on production of the toxin. Brit. J. exp. Path. 34, 221. 
Kaufman, L. \& Humphries, J. C. (1958). Studies on the nutritional requirements of Clostridium tetani. 1. A chemically defined medium. Appl. Microbiol. 6, 311.

KLIENEBERGER, E. (1936). Further studies on Streptobacillus moniliformis and its symbiot. J. Path. Bact. 42, 587.

KoDICEK, E. (1949). The effect of unsaturated fatty acids on Gram-positive bacteria. Symp. Soc. exp. Biol. 3, 217.

Laidlaw, P. P. \& Elford, W. J. (1936). A new group of filterable organisms. Proc. roy. Soc. B, 120, 292.

LeY, H. L., Jr. \& Mueller, J. H. (1946). On the isolation from agar of an inhibitor for Neisseria gonorrhoeae. J. Bact. 52, 453.

Magasanik, B. (1957). Nutrition of bacteria and fungi. Annu. Rev. Microbiol. 11, 221.

Medill, M. A. \& O'Kane, D. J. (1954). A synthetic medium for the $L$ type colonies of Proteus. J. Bact. 68, 530.

Morton, H. E., Smith, P. F. \& Leberman, P. R. (1951). Investigation of the cultivation of pleuropneumonia-like organisms from man. Amer. J. Syph. 35, 361 .

Pollock, M. R. (1949). The effects of long chain fatty acids on the growth of Haemophilus pertussis and other organisms. Symp. Soc. exp. Biol. 3, 193.

Razin, S. \& KNight, B. C. J. G. (1960b). The effects of ribonucleic acid and deoxyribonucleic acid on growth of Mycoplasma. J. gen. Microbiol. 22, 504.

Rodwell, A. W. (1956). The role of serum in the nutrition of Asterococcus mycoides. Aust. J. biol. Sci. 9, 105.

Rodwell, A. W. (1960). The nutrition and metabolism of Mycoplasma mycoides var. mycoides. Ann. N.Y. Acad. Sci. 79, 499.

Smrth, P. F. (1955). Synthetic media for pleuropneumonialike organisms. Proc. Soc. exp. Biol., N.Y. 88, 628.

Smith, P. F., LeCCE, J. G. \& LYNN, R. J. (1954). A lipoprotein as a growth factor for certain pleuropneumonialike organisms. J. Bact. 68, 627.

Smith, P. F. \& LynN, R. J. (1958). Lipid requirements for the growth of pleuropneumonialike organisms. J. Bact. 76, 264.

Traub, A., Mager, J. \& Grossowicz, N. (1955). Studies on the nutrition of Pasteurella tularensis. J. Bact. 70, 60.

Tulasne, R., Terranova, T. \& Lavillaureix, J. (1955). Obtention des formes de diverses bactéries à gram negatif sur des milieux sans sérum mais contenant des vitamines du groupe B. Giorn. Microbiol. 1, 44.

(Received 22 September 1959) 